\title{
Study of Dramaturgy Applied by The Selected Bureau of Architectural Consultants in Indonesia
}

\author{
Hasaruddin Amir ${ }^{1}$, Asta Juliarman $\operatorname{Hatta}^{2}$, Andi Abidah ${ }^{3}$ \\ ${ }^{1}$ Graduate student of Architecture Study Program, Universitas Negeri Makassar, Indonesia \\ 2), 3) Department of Architecture, Universitas Negeri Makassar, Indonesia
}

Manuscript received:

8 July 2021

Manuscript revised:

26 August 2021

Manuscript accepted:

31 August 2021

Date of publication:

31 August 2021

Corresponding author:

Name:

Asta Juliarman Hatta

Email:

astajuliarmanhatta@gmail.com

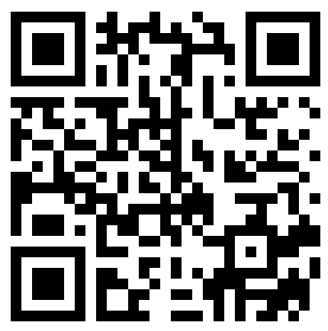

Abstract - Every architect has a different view and thought about something in designing a building. The basis of ideas design to a building is gained from experience, imagination, creativity, education, etc. Every professional architect also owns cognitive to express how the architecture works implemented through the design of a building. In architecture, there is a theory that connects drama and architecture in everyday life, dramaturgy. This article aims to see the concepts of dramaturgy in the works of the architectural consulting bureau responsible for, Omah Boto building, Aceh Tsunami Museum, and Phinisi Unm Tower. This study uses a qualitative method with data collection carried out using literature studies. Furthermore, the analyzed data is then presenting in descriptive for a more informative series. Data analysis aims to explore the relevance of the dramaturgy application in architecture to the thinking of architects in Indonesia. The results of the study show dramaturgy in architecture is used as a match between contemporary theater art and architecture. All three architectural consultants have used elements of dramaturgy in the design process. The three architectural consultants have used aspects of dramaturgy in their design process. The application of the basic concepts of dramaturgy used is an exterior setting of the building, Goals or ideas, building layout settings, visual instructions, and motion direction.

Keywords: architecture, architecture consultant, dramaturgi

\section{INTRODUCTION}

Houses, rental offices, hotels or other types of buildings are architectural works of a person, company, institution, or consulting firm. An architectural consulting bureau comprises a team or group specifically engaged in architectural work such as building projects, interiors, facades, and other architectural work. Each architectural consulting bureau has its own characteristics and vision that can be seen in the construction of a building. Andy Rahman Architect, PT. Urbane Indonesia, and Akanoma Studio represent architectural consulting firms experienced in working on many building projects like residential buildings, flats, schools, rental offices, and other building projects. Each architectural consulting bureau embodies a characteristic known by its architects acting as leaders in the development projects. 
Andi Rahman Architect Office Building is one of the works of a notable architect named Andi Rahman. Andi Rahman is a professional architect appreciated for his architectural works that collaborate with the game and arrangement of bricks with a mixture of concrete materials. Then, the prominent building of the PT Urbane Indonesia architectural bureau designed by Ridwan Kamil is the Aceh Museum building. This building represents a building that has an extraordinary impression and social value for the people of Aceh considering the 2004 Aceh tsunami. Studio Akanoma is, moreover, an architectural consulting firm well known for Yusing's role as an architect. Yusing's works of thought have been known as "pro-people" ideas, architectural and efficient buildings to accommodate all levels of society with straightforward designs and moderate prices.

Every architect has alternative views and thoughts about something. This can be obtained based on experience, imagination, creativity, education, and other things. Each architect, in addition, occupies his own line of thought used to explain how an architectural work can be expressed through building design. In the world of architecture, a theory connects drama and architecture in customary life, namely dramaturgy (Tawalujan \& Sela, 2012). The meaning of drama, in this case, represents an expressive approach where a person is considered as one of the most substantial factors in designing a literary work. Etymologically, dramaturgy is the skill and technique of composing a dramatic work which is an emotional plot in a story. The story line is the result of someone's expression who dominates the drama with his thoughts, feelings, and views.

In terms of drama and architecture, in this case, the role of the architect can be positioned as a director because the architect is considered to have a responsibility in the process of developing a storyline until the formation of a building work that bears a soul. According to (Tawalujan \& Sela, 2012), the analogy of dramaturgy can be seen from two points of view, first the actor and second the scriptwriter. From the actor's point of view, it is the architect's role to pay attention to the tools and equipment needed to perform a particular role. Then from the point of view of the playwright, the architect acts like a puppeteer. In this case, the architect can cause people to transport from one place to another by providing visual clues.

Based on the explanation above, the scope and focus of the discussion in this article is to explore the role of leading architects in architectural consulting bureaus in Indonesia. The discussion related to the analogy of dramaturgy in architecture will discuss how a consulting bureau with the architects involved can design an architectural work like a stage play which is the hallmark and pride of the consulting bureau in fighting for its existence in architecture.

\section{METHODOLOGY}

This study employs a qualitative method with data collection carried out using literature studies in books, journals, and scientific articles related to dramaturgy studies on the work of architectural consulting bureaus in Indonesia. The case study that is the object of the research is Andi Rahman Architect, PT. Urbane Indonesia, and Studio Akanoma. The selection of a consulting firm is based on the experience of an architectural consulting firm that has worked for several years. The identity and characteristics of each consulting bureau, as well as the ideas and concepts of the architect's work are taken into consideration in the selection of research objects. Dramaturgy study in architecture is an absorbing topic or issue to be raised and discussed. Dramaturgy and architecture both possess their own atmosphere to discuss their scientific substance. Between the two substances, a common thread can be drawn to discover recent knowledge that can be poured into architectural science. The novelty of research on this topic in the world of architecture is still rarely studied, so the author feels the need for further discussion.

The data collected will then be analyzed descriptively for a more informative presentation of the data. The data analyzed descriptively aims to determine the relevance of the application of dramaturgy in architecture to the thinking of architects in Indonesia. In the case of this qualitative research, the selection of informants is only limited to one informant for each architect's work from each consulting bureau. The selection of one informant was selected based on the adequacy and suitability of the information needed. The adequacy requirement is met by determining the number of informants who provide sufficient information. This leads to the benchmark for researchers in determining the number of informants to be not on representation but on the depth of information. 


\section{RESULTS AND DISCUSSION}

\section{A. Theoretical Study of Dramaturgy in Architectural Practice}

According to Goffman (1978), dramaturgy represents a theory suggesting social interaction in mortal life to have the same meaning as theater and drama. This can be related to mortal life like a stage or theater displaying a role (Suneki \& Haryono, 2012). Principally, dramaturgy theory represents an approach describing a person's personal life as a stage whose stage to be complete with stage settings and actors who perform an act. Goffman (1978) said that an important factor in dramaturgical theory is how the concepts and relationships between the individual and the audience can be applied to a particular time and place. In this case, the concept can be implemented through impression management where each individual must direct his thoughts, works, and presentation to observe the audience's response to the concept presented. Concepts in dramaturgy can furthermore be expressed as a script, which is a concept and work that can be communicated and staged. Thus, the audience believes in what will be presented. The concept contains the context in which information, language, and behaviour will be presented by someone in a particular event or work.

Currently, the architectural profession represents a rapidly growing profession in Indonesia. This can be perceived from the many consulting bureaus established, such as Andi Rahman Architect, PT. Urbane Indonesia, Akanoma Studio, and other architectural consultants. The role of architectural consultants features physical development in Indonesia. The physical development built includes buildings such as hotels, offices, housing, and development facilitation in slum areas.

The architect profession itself represents a profession that has been recognized as a profession that carries out building work, especially in terms of design and construction services (Tutuko, 2014). For example, several architectural consultants study one focus of work such as interior work, facades, housing, high-rise buildings, and other jobs. However, in architectural practice, every architectural consultant must allow an architect who is registered as a member of the IAI (Indonesian Institute of Architects). The IAI was formed as an organization that overshadows all problems in the architectural profession, especially in the architect's code of ethics and code of ethics for the architectural profession (Indonesia, 2007). This is done so that the profession of architects and architectural consulting bureaus get official work permits and gain the trust of clients to handle a development project. This is also done so that the projects being carried out do not fail and do not violate regulations such as environmental disturbances, the existence of aggrieved parties, and the destruction of cultural values in historic buildings or cultural heritage.

In the world of architecture, dramaturgy has become a part of architecture (Turner, 2015). Dramaturgy itself is used as an analogy that explains the relationship between architecture and drama. According to Snyder \& Catanese (1984), dramaturgy is the skill and technique of composing dramatic works where the work contains an emotional plot in a story. The relationship related to dramaturgy and architecture can be seen in the role of the architect who is positioned as a director where the architect has responsibility in the process of developing the storyline of a building work that bears a soul.

The concept of dramaturgy in architecture can be identified from two points of view, namely the actor's point of view and the scriptwriter's point of view (Tawalujan \& Sela, 2012). From the actor's point of view, in this case, the role of the architect will pay attention to the tools and equipment needed to perform a certain role. This includes setting clothes to beautify the appearance of the actors, the actors requiring a mechanism to get off the stage to "be themselves", and the stage setting is arranged in such a way for stage performances. From the point of view of the playwright, the architect acts like a puppeteer, where the architect can cause people to transport from one place to another by providing visual clues. The concept of dramaturgy analogy in architecture can be reflected in table 1 .

Table 1. Application of Dramaturgy Concepts in Architecture

\begin{tabular}{|l|l|l|c|}
\hline No & \multicolumn{1}{|c|}{ The basic concept of dramaturgy } & Concept Description \\
\hline 1. & Actor's Point of View. & $\begin{array}{l}\text { Setting clothes to beautify the appearance } \\
\text { of the actors. }\end{array}$ & Building exterior setting. \\
\cline { 2 - 4 } & $\begin{array}{l}\text { Architects pay attention to the tools } \\
\text { and equipment needed to play a } \\
\text { particular role. }\end{array}$ & $\begin{array}{l}\text { Actors need a mechanism to get off the } \\
\text { stage to "be themselves". }\end{array}$ & Goals, ideas or ideas. \\
\hline
\end{tabular}


Study of Dramaturgy Applied by The Selected Bureau of Architectural Consultants in Indonesia

\begin{tabular}{|c|c|c|c|}
\hline No & \multicolumn{2}{|c|}{ The basic concept of dramaturgy } & Concept Description \\
\hline & & $\begin{array}{l}\text { The stage setting is arranged in such a } \\
\text { way for stage performances. }\end{array}$ & Building Layout Settings. \\
\hline \multirow[t]{2}{*}{2.} & \multirow{2}{*}{$\begin{array}{l}\text { Playwright's Point of View } \\
\text { For example, the direction of motion } \\
\text { from the entry point to the auditorium } \\
\text { space, the architect can cause the } \\
\text { audience to fill the space in a certain } \\
\text { way. }\end{array}$} & $\begin{array}{l}\text { Architects can cause people to move in } \\
\text { one direction or another by providing } \\
\text { visual clues. }\end{array}$ & Visual instructions. \\
\hline & & $\begin{array}{l}\text { Illuminated areas in the context of } \\
\text { darkness will attract one's movements. }\end{array}$ & Motion Direction. \\
\hline
\end{tabular}

\section{B. Dramaturgy Studies in the Professional Practice of the Bureau of Architecture}

Dramaturgy studies is discussed in the selected works of the three architectural consulting bureaus in Indonesia. The works from Architect Andy Rahman are the Omah Boto building, from PT. Urbane Indonesia is the Aceh Tsunami Museum, and from Akanoma studio, one of the works that will be studied is the Phinisi UNM Tower.

\section{Dramaturgy Study of Omah Boto Building}

Andy Rahman Architect is an architectural consultant founded by Andy Rahman in 2006 and is one of the leading architectural consultants in Indonesia. This can be marked from his experience in working on several development projects such as residential houses, rental offices, hotels, and other buildings. Andy Rahman is a professional architect and architectural graduate from the Ten November Institute of Technology. This building work by Andy Rahman Architect is known as a work that collaborates on the game and arrangement of bricks with a mixture of concrete materials. In this case, the discussion of dramaturgy in architecture will be considered in one of the works of Architect Andi Rahman, namely the Omah Boto building (figure 1).

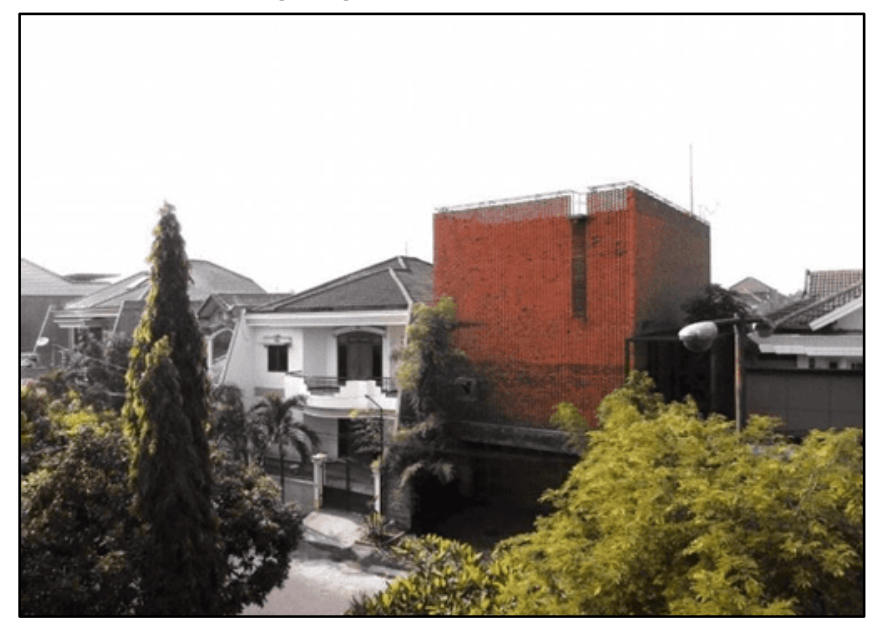

Fig. 1. Omah Boto Building

Source: Wijaya et al. (2019)

In the arrangement of the exterior appearance of the building, the dominant brick material seems to have described the appearance of the building in accordance with the idea and idea of naming "Omah Boto." Omah Boto itself suggests brick house. The brick material has conveyed a pleasant impression on the exterior appearance of the house where the brick material describes the atmosphere of the archipelago originating from Indonesia. According to Wijaya et al. (2019), the ideas to make Omah Boto were created from the results of conversations with clients. In this case, Andy Rahman was desired to develop a building describing the atmosphere of the archipelago in accordance with the wishes of clients who want to possess a house and be known as the house of Indonesia.

In setting the layout of the Omah Boto building, the application of brick material is not only displayed on the exterior of the building but on the interior of the building. On the floor, walls, and ceiling, the arrangement of bricks with various motifs is also highlighted. The arrangement of brick motifs on several walls has varied functions and concepts. This can be perceived in the bedroom, prayer 


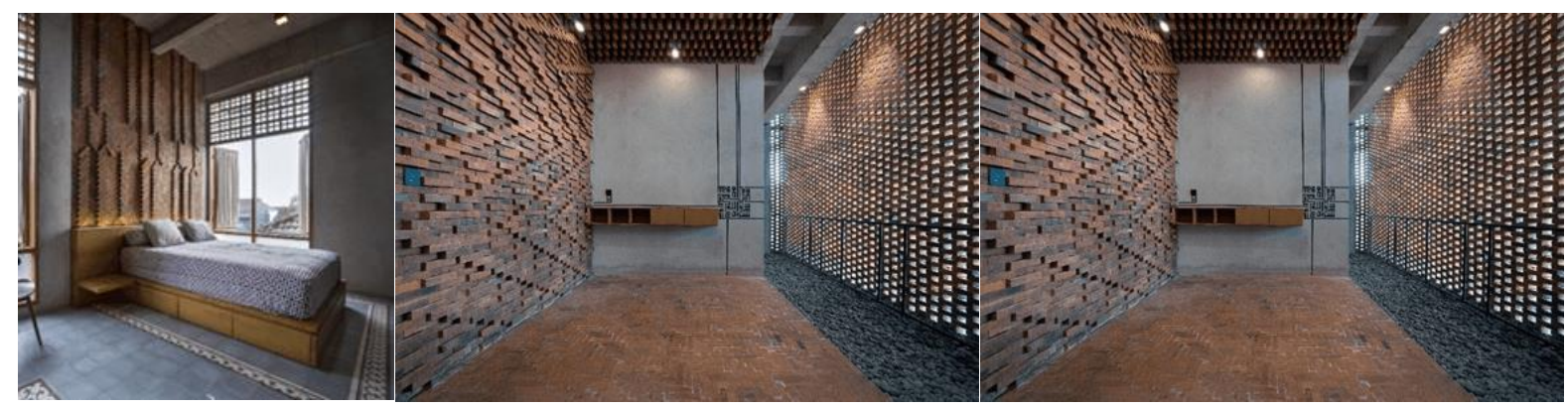

Fig. 2. Bedroom, prayer room, circulation of stairs area Source: Wijaya et al. (2019); archdaily.com. (2019)

On the bedroom wall, Andy Rahman arranged bricks with Javanese batik motifs, namely the Pucung Rebung batik motif (Wijaya et al. 2019). This is performed to illustrate there is value in the concept of a traditional Javanese house in Omah Boto. Then the arrangement of bricks on the walls of the prayer room using a machete batik motif. The intriguing thing is perceived in the stair's circulation area where the bricks on the walls are arranged with motifs so that air and sunlight can enter willingly. An intriguing thing is equally detected in the shadow pattern formed on the wall due to the incoming sunlight. The shadow pattern formed will be different in the morning, afternoon, and evening due to the influence of the angle of the incoming sunlight. This is what produces the appearance of the Omah Boto section obtains a naturally pleasant impression that generates one want to experience the atmosphere of the display of light entering the area.

\section{Dramaturgy Study of the Aceh Tsunami Museum Building}

PT Urbane Indonesia is an architectural consulting firm founded by Ridwan Kamil and his colleagues in 2004 (Daniel, 2007). PT. Urbane himself is an architectural consultant who has handled several development projects in Indonesia and has participated in many design competitions. According to Daniel (2007), Urbane essentially exhibits the characteristics and motto of "progressive thinking" where the exploration of modern architectural spaces can be done through design methodology experiments, namely the analogy method. Urbane, in addition, utilizes the principle that one's ability and creativity in designing will not be enough to compete globally. Therefore, an understanding of global culture, property, and the market economy represent mandatory knowledge that must be mastered by architects at the Urbane bureau. In this case, the discussion of dramaturgy in architecture in one of the works of PT. Urbane Indonesia comprise the building of the Aceh Tsunami Museum (figure 3).
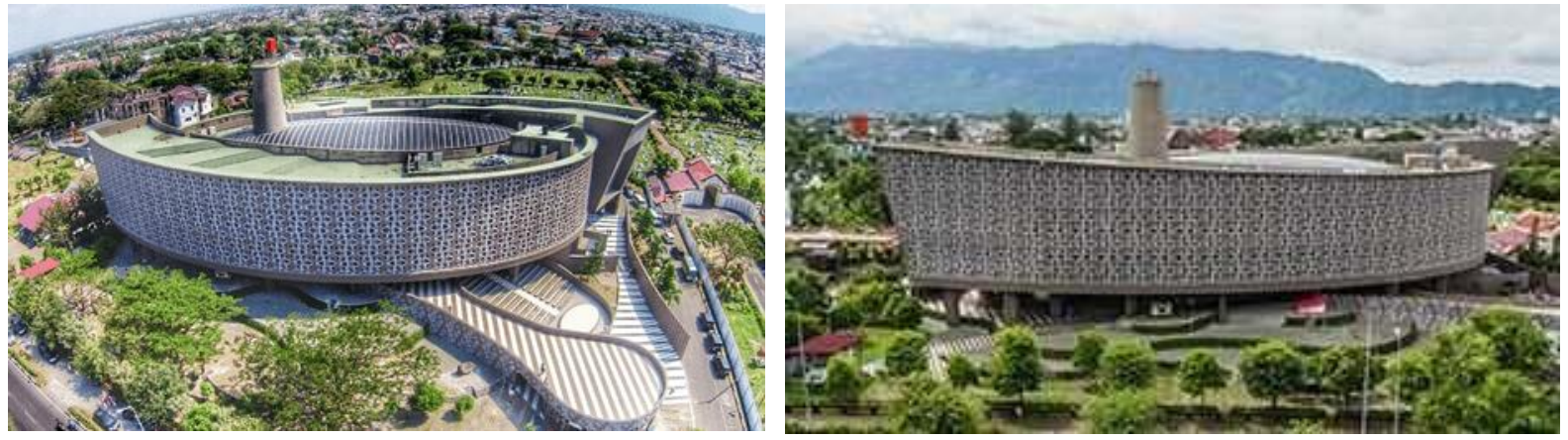

Fig. 3. Aceh Tsunami Museum Building

Source: https://penanegeri.com/; http:/tempatwisataunik.com

The Aceh Tsunami Museum comprises a building occupied as a place and container for exhibition space to remember various tsunami events in 2004 in Banda Aceh (Dafrina, 2019). The ideas designed by Ridwan Kamil were built with the aim of becoming a symbol of the strength of the Acehnese people in dealing with disasters and serving as shelter in the future. From the outside of the building, 
this building is designed to resemble a ship docked and has the concept of the saman dance which is applied to decorative ornaments on the facade. In setting the layout, there are several concepts used, namely escape hill, sea waves, God's light and a garden for the community (public part).

The Aceh Tsunami building consists of four floors and is decorated with Islamic nuances. On the ground floor there is a public room with a pool in the middle as a resting and reflection room for visitors. The first room that visitors will encounter in this building is the contemplation room where in this room there is a narrow and dimly lit hallway (Nazaruddin \& Sulaiman, 2013). In this hallway, visitors can perceive the sound of gurgling water on the left and right of the wall. The sound of gurgling water is likened to the roar that occurs during a tsunami (figure 4).
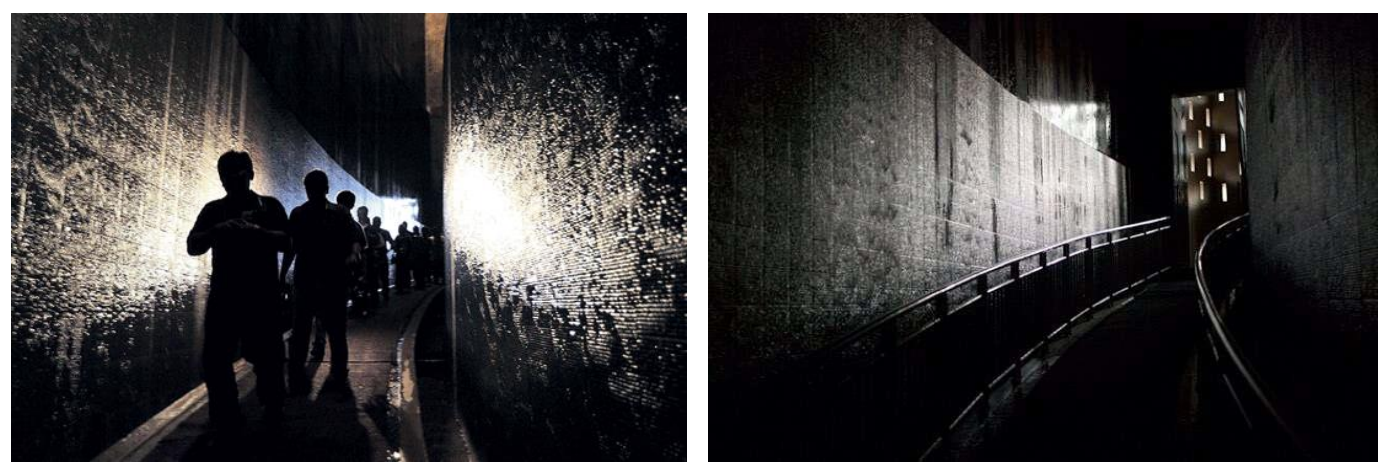

Fig.4. Aceh Tsunami Museum Contemplation Room

Source: https://penanegeri.com/; http:/tempatwisataunik.com

On the second floor, the following room is secured after passing through the contemplation room, namely the memorial hill. This is where information will be displayed through a monitor regarding sharing events that occurred during the tsunami. After that, the adjacent room that you will discover is "The Light of God", where the walls of this room are occupied with the names of the victims who died in the tsunami event (figure 5). An attractive thing is equally exposed on the roof of the elevated part of the room, namely the presence of Allah's writing with illuminating light. This concept is demonstrated as a spiritual form of the Acehnese people to recognize God for the events that have occurred (Rahman et.al. 2014). On the 3rd floor of the Aceh Tsunami Museum, there is a geology room where visitors can get information and displays related to disasters, especially earthquakes and tsunamis. This room is also equipped with several facilities such as geology room, library, prayer room, and souvenir room. On the last floor, this room is operated as an escape building, which remains a place of rescue for the people of Aceh in the event of a tsunami in the future.
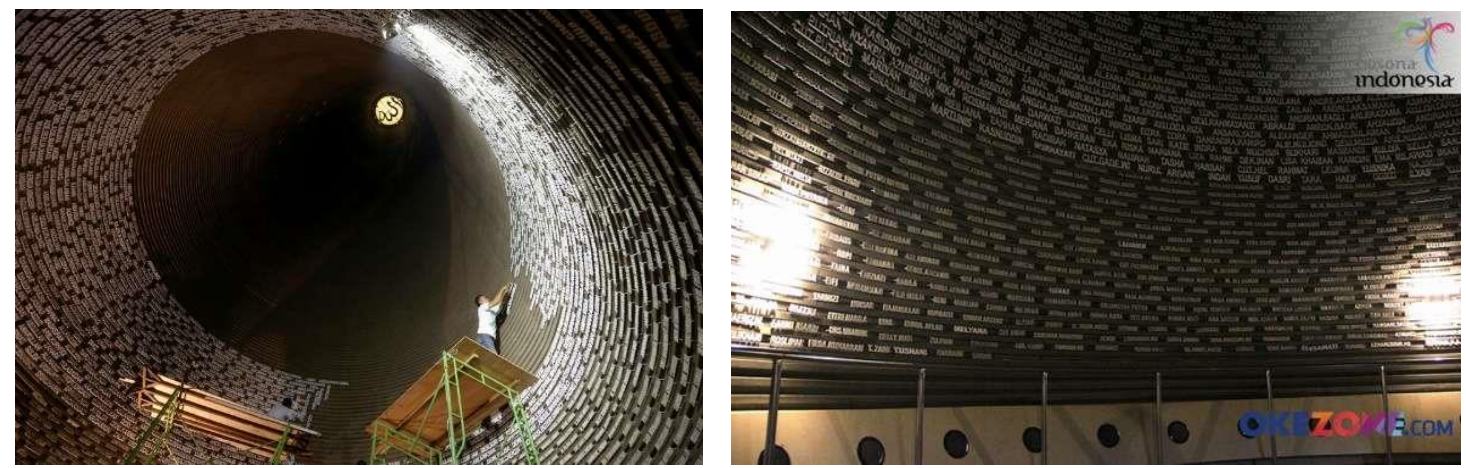

Fig. 5. God's light room

Source: https://nusantarakaya.com/; https://lifestyle.okezone.com/

\section{Dramaturgy Study of the UNM Phinisi Tower Building}

Studio Akanoma is an architectural consultant founded by Yusing and his colleagues in 2008. Customarily, Yusing is known as an architect who cares about the community. Akanoma itself is an abbreviation of the root of anomaly, meaning the studio must be committed to being rooted in the cultural context, potential and problems that exist in Indonesia. In this case, the discussion of dramaturgy 
in architecture will be considered in one of Akanoma's works designed by Yusing, namely the Phinisi UNM tower building. The Phinisi UNM tower building comprises a building designed by Yusing using the cultural concepts, philosophical values, culture, and traditional Makassar architecture (Winarni, 2019). This can be noted from the shape of the building that takes the concept of a phinisi boat. The philosophy of this phinisi building is also designed like a Makassar stilt house which consists of the bottom of the house, the body of the house, and the top of the house. This can be regarded in the phinisi building which possesses a building under the building, then in the middle of the building there is a building podium and above the building there is a 17-story building tower (figure 7).

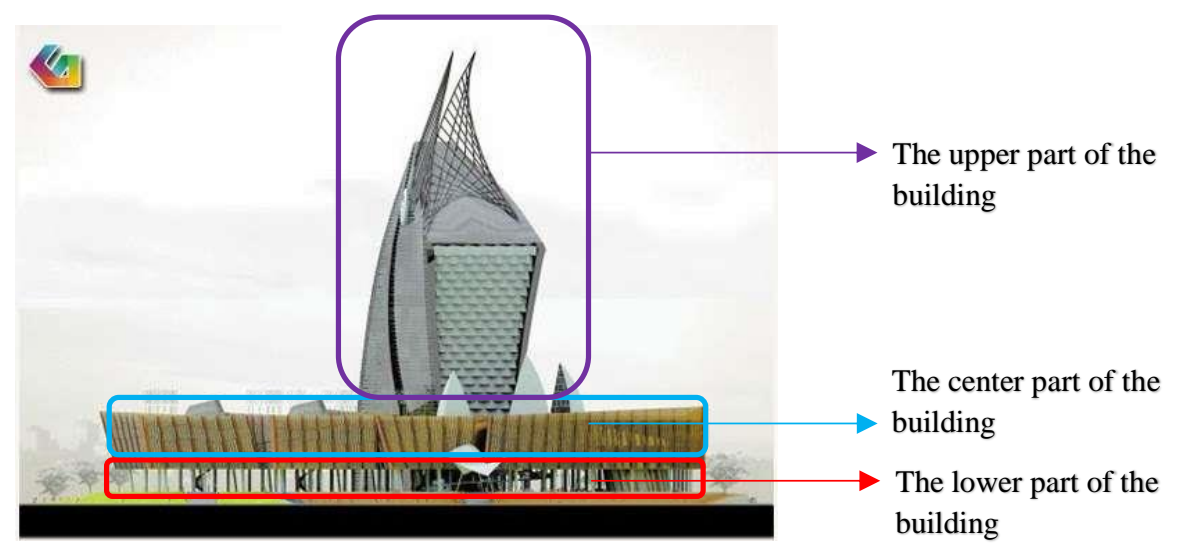

Fig. 6. Application of the concept of a traditional house on the Phinisi UNM tower building.

Source: http://archiholic99danoes.blogspot.com/

In the layout of the lower building, under the building there is an open space under the podium used for socializing together (figure 7). This philosophy is established from the habits of the BugisMakassar people who repeatedly discuss under the house. At that time other pleasing things were also noted on the facade of the building that uses Hyperbolic Paraboloid which is a futuristic application of the sophistication of science and technology (Latif et.al. 2017). The design of this facade is shaped in such a way that a rhombus is developed which is used as a place for air circulation (figure 8). The shape of the rhombus is assumed from the basic form (sa) of the philosophy of sulapa eppa'e, namely the philosophy of life of the Bugis-Makassar people (Mattulada, 1985).
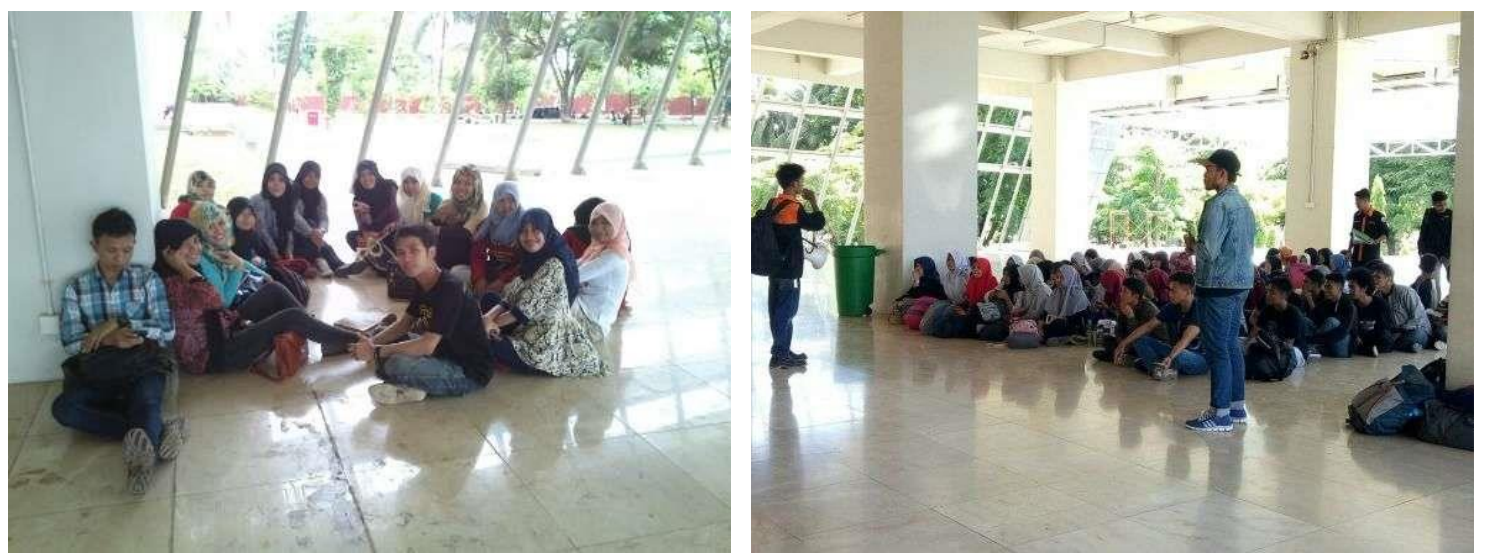

Fig. 7. The underside of the Phinisi UNM tower building as a social space. Source: http://estetikapers.com/ 

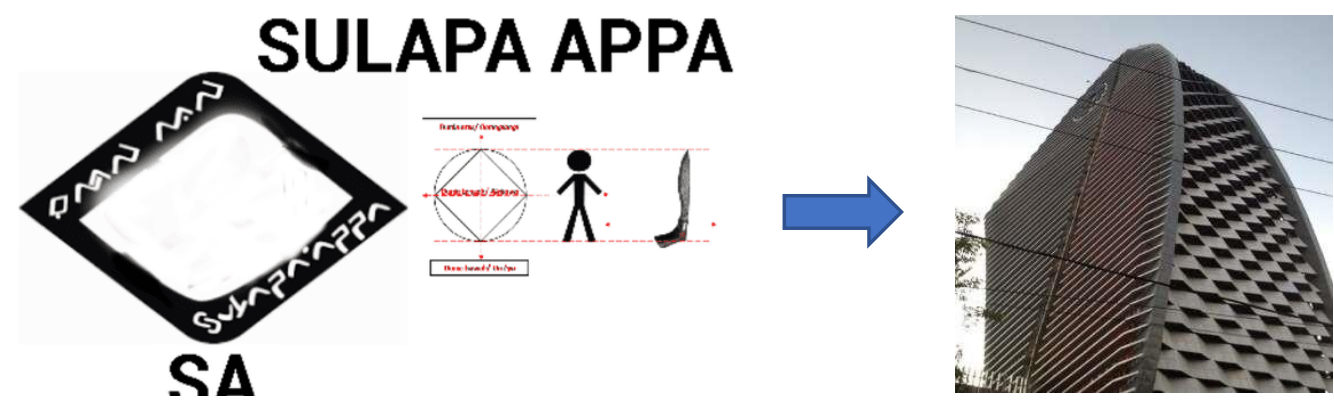

Fig. 8. Application of the letter Sa to the facade of the building.

Source: https://amscentre.wordpress.com/; https://id.foursquare.com/

4. Summary of the analysis of dramaturgy study the three architectural consulting bureaus.

A summary of explanations regarding dramaturgy studies in architecture in 3 building cases responsible for Omah Boto, Aceh Tsunami and UNM Phinisi Tower can be seen in table 2.

Table 2. Dramaturgy Study of Omah Boto, Aceh Tsunami Museum, and UNM Phinisi Tower.

\begin{tabular}{|c|c|c|c|c|c|c|}
\hline No & \multicolumn{2}{|c|}{$\begin{array}{l}\text { Basic Concepts of } \\
\text { Dramaturgy }\end{array}$} & $\begin{array}{l}\text { Concept } \\
\text { Description }\end{array}$ & $\begin{array}{l}\text { Omah Boto } \\
\text { Building }\end{array}$ & $\begin{array}{l}\text { Museum Tsunami } \\
\text { Aceh Building }\end{array}$ & $\begin{array}{l}\text { Phinisi UNM } \\
\text { Tower Building }\end{array}$ \\
\hline \multirow[t]{3}{*}{1.} & \multirow[t]{3}{*}{$\begin{array}{l}\text { Actor's } \\
\text { Point of } \\
\text { View. }\end{array}$} & $\begin{array}{l}\text { Setting clothes } \\
\text { to beautify the } \\
\text { appearance of } \\
\text { the actors. }\end{array}$ & $\begin{array}{l}\text { Exterior } \\
\text { setting of } \\
\text { the } \\
\text { building. }\end{array}$ & $\begin{array}{l}\text { The dominant use } \\
\text { of brick material } \\
\text { is in accordance } \\
\text { with the name of } \\
\text { the building. }\end{array}$ & $\begin{array}{l}\text { The concept of } \\
\text { Saman dance is } \\
\text { applied to decorative } \\
\text { ornaments on the } \\
\text { facade. }\end{array}$ & \multirow{3}{*}{$\begin{array}{l}\text { The concept of } \\
\text { Sulapa Eppa's } \\
\text { philosophy, the } \\
\text { philosophy of } \\
\text { traditional } \\
\text { houses and the } \\
\text { life philosophy } \\
\text { of the Makassar } \\
\text { people are used } \\
\text { as guidelines in } \\
\text { designing } \\
\text { exteriors, } \\
\text { building forms, } \\
\text { building layouts } \\
\text { and building } \\
\text { facades. }\end{array}$} \\
\hline & & $\begin{array}{l}\text { Actors need a } \\
\text { mechanism to } \\
\text { get off the } \\
\text { stage to "be } \\
\text { themselves". }\end{array}$ & $\begin{array}{l}\text { Goals, ideas } \\
\text { or ideas. }\end{array}$ & $\begin{array}{l}\text { Brick material as } \\
\text { the architectural } \\
\text { identity of the } \\
\text { Indonesian } \\
\text { archipelago. }\end{array}$ & \multirow{2}{*}{$\begin{array}{l}\text { Designed as a place } \\
\text { to remember the } \\
2004 \text { Aceh Tsunami. } \\
\text { The concepts used } \\
\text { are escape hill, ocean } \\
\text { waves, God's light } \\
\text { and park for the } \\
\text { community (public } \\
\text { part) }\end{array}$} & \\
\hline & & $\begin{array}{l}\text { The stage } \\
\text { setting is } \\
\text { arranged in } \\
\text { such a way for } \\
\text { stage } \\
\text { performances. }\end{array}$ & $\begin{array}{l}\text { Building } \\
\text { Layout } \\
\text { Settings. }\end{array}$ & $\begin{array}{l}\text { The exterior and } \\
\text { interior are } \\
\text { dominated by the } \\
\text { use of brick } \\
\text { material to give } \\
\text { the impression of } \\
\text { the archipelago. }\end{array}$ & & \\
\hline \multirow[t]{2}{*}{2.} & \multirow[t]{2}{*}{$\begin{array}{l}\text { Dramatic } \\
\text { Point of } \\
\text { View. }\end{array}$} & $\begin{array}{l}\text { Architects can } \\
\text { cause people } \\
\text { to move in one } \\
\text { direction or } \\
\text { another by } \\
\text { providing } \\
\text { visual cues. }\end{array}$ & $\begin{array}{l}\text { Visual } \\
\text { Instructions }\end{array}$ & \multirow[t]{2}{*}{$\begin{array}{l}\text { Separation of } \\
\text { space is formed } \\
\text { with the motif of } \\
\text { arrangement of } \\
\text { bricks as a space } \\
\text { separator. }\end{array}$} & \multirow[t]{2}{*}{$\begin{array}{l}\text { The atmosphere of } \\
\text { the Tsunami can be } \\
\text { remembered and felt } \\
\text { in the meditation } \\
\text { room and God's Light } \\
\text { room. }\end{array}$} & \multirow{2}{*}{$\begin{array}{l}\text { The concept of a } \\
\text { traditional } \\
\text { Makassar house } \\
\text { is applied to } \\
\text { under the } \\
\text { building where } \\
\text { the space is used } \\
\text { as a social space } \\
\text { that describes } \\
\text { the habits of the } \\
\text { Bugis-Makassar } \\
\text { people when } \\
\text { socializing under } \\
\text { the house. }\end{array}$} \\
\hline & & $\begin{array}{l}\text { An area } \\
\text { illuminated in } \\
\text { the context of } \\
\text { darkness will } \\
\text { attract a } \\
\text { person's } \\
\text { movement. }\end{array}$ & $\begin{array}{l}\text { Motion } \\
\text { Direction. }\end{array}$ & & & \\
\hline
\end{tabular}

In the case of the Omah Boto building, from the actor's point of view, the architect has performed a certain dramatic role in the stage to become himself, namely by improving the appearance of the building on the exterior of the building. The arrangement of the exterior of the building with the use of the dominant brick material makes the Omah Boto building have an Indonesian architectural identity. On that occasion in the playwright's point of view, the architect has provided visual instructions 
and motion directions to room users by arranging different motifs in each room so that space users will move to follow the whole atmosphere in the house.

In the case of the Aceh Tsunami Museum building, from the actor's point of view, the architect has performed a certain dramatic role in the stage to become himself, namely by improving the appearance of exterior and setting the interior. The exterior arrangement of the building represents the use of the Saman dance concept which is applied to the decoration ornaments on the facade. At that point, in the playwright's point of view, the architect has provided visual instructions and motion directions to the room users by giving the impression, memory, and atmosphere of the Tsunami incident in the concept of the contemplation room or commonly called the light of God.

In the case of the UNM Phinisi Tower building, from the actor's point of view, the architect has played a certain drama role in the stage to be himself. This is by improving the appearance of the building on the exterior of the building and setting the interior of the building. The exterior arrangement of the building represents the use of the concept of Sulapa Eppa's philosophy as a guide for designing the exterior, shape, layout, and facade of the building. Subsequently, in the perspective of the playwright, the architect has provided visual instructions and motion directions to the room users using the traditional Bugis-Makassar house concept and applied to the underside of the building where the space is utilized as a socializing space that describes the Bugis-Makassar people's habits when socializing with other people.

\section{CONClusion}

In most cases, the application of dramaturgy studies in architecture has been applied by every architectural consulting bureau in Indonesia. This can be perceived from the results of dramaturgical studies on the works of Omah Boto, the Aceh Tsunami Museum, and the UNM Phinisi Tower that there is a use of the core concept of dramaturgy. Indirectly the ideas, concepts, and ideas of architects in designing a building have thought about how the dramaturgy concept is used on the elements or parts of the building. This includes clothes to beautify the appearance of the actors, actors requiring a mechanism to get off the stage to "be themselves", and the stage setting arranged in such a way for stage performances. From the point of view of the playwright, the architect acts like a puppeteer, where the architect can cause people to transport from one place to another by providing visual clues and, an area illuminated in the context of darkness will attract a person's movement. However, typically, architects do not yet have limited knowledge of the concept of proper and detailed dramaturgy and how it relates to the science of architectural design. The results of research on the core concepts of dramaturgy in architecture are still very limited, therefore similar research based on the perspective of other architects needs to be carried out and studied more thoroughly. Comparison of the perspective of other architects within the scope of architects in Indonesia needs to be studied more thoroughly to explore knowledge and add to the discourse in the world of architecture.

\section{ACKNOWLEDGEMENT}

The researcher would like to thank colleagues who have helped in the data collection process. The researcher also thanks fellow students and lecturers of the department of architecture at the Universitas Negeri Makassar who provided input and enthusiasm in writing articles.

\section{REFERENCES}

Dafrina, A. (2019). Penerapan Arsitektur Metafora Pada Museum Tsunami Aceh Di Banda Aceh. Jurnal Arsitekno, 2(2), 1-8.

Daniel, F. (2007). Kompilasi Artikel Proyek dan Desain Arsitektur pada Majalah Indonesia-Architecture (iARCH). Architectural Design Articles.

Goffman, E. (1978). The presentation of self in everyday life. London: Harmondsworth.

Ikatan Arsitek Indonesia (2007). Kode Etik Arsitek dan Kaidah Tata Laku Profesi Arsitek. Jakarta: Badan Sistem Informasi Arsitektur Ikatan Arsitek Indonesia. 
Study of Dramaturgy Applied by The Selected Bureau of Architectural Consultants in Indonesia

Latif, S., Jamala, N., \& Sam, S. (2017). Pengaruh Desain Fasade Bangunan terhadap Distribusi Pencahayaan Alami pada Gedung Menara Phinisi UNM. Jurnal Lingkungan Binaan Indonesia, 6(1), 59-64. https://doi.org/10.32315/jlbi.6.1.59

Mattulada, L. (1985). LATOA: Satu Lukisan Analitis terhadap Antropologi Politik Orang Bugis (Doctoral Disertation). Universitas Indonesia

Nazaruddin, D. A., \& Sulaiman, R. (2013). Introduction to "Tsunami Tourism": notes from Aceh, Indonesia. International Journal of Sciences, 2(Mar), 71-81.

Rahman, A., Sari, S. A., \& Ridha, M. (2014). The Development Aceh Tsunami Museum Documentary on SECI Model of Knowledge Management. The International Journal of Social Sciences, 19(1), 136-145.

Snyder, J. C., \& Catanese, A. (1984). Pengantar Arsitektur. Jakarta: Erlangga.

Suneki, S., \& Haryono, H. (2012). Paradigma Teori Dramaturgi terhadap Kehidupan Sosial. CIVIS, 2(2/Juli).

Tawalujan, Y., \& Sela, R. L. E. (2012). Analogi Dramaturgi Dalam Rancangan Arsitektur. Media Matrasain, 9(1), 75-88.

Tutuko, P. (2014). Teori Kontrak Sosial Terhadap Fenomena Pendidikan, Profesional, Dan Legalitas Arsitek. Seminar Nasional Arsitektur: Profesional Dan Legalitas. Surabaya: Teknik Arsitektur UPN "Veteran."

Wijaya, A. R., Kusumarini, Y., \& Suprobo, F. P. (2019). Manifestasi Nusantara Mengkini pada Konsep Karya Interior Arsitektur Andy Rahman (Studi Kasus: Omah Boto). Intra, 7(2), 1-9.

Winarni, S. (2019). Penerapan Unsur Arsitektur Nusantara Pada Karya Desain Arsitek Yu Sing. PAWON: Jurnal Arsitektur, 3(1), 25-34. 